\title{
Mineral Activities of the U.N.
}

Department of Technical Co-operation for Development

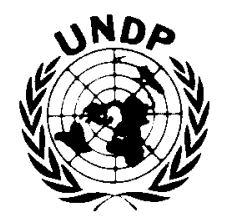

\author{
by J. Guy-Bray and Michael Lewis
}

The principal United Nations agency for mineral resource exploration and development is its Department of Technical Co-operation for Development. Since 1959 DTCD has spent some US $\$ 300$ million on mineral projects, which have resulted in the discovery of ore deposits valued at several tens of billions of dollars. This article reviews the activities of the DTCD minerals program, which range from policy and legislation through exploration and evaluation to mining, processing and marketing, including support for training, strengthening of government facilities, introduction of new technologies, and specialized advisory services.

\section{Introduction: UNDP and DTCD}

In 1958 the Special Fund of the United Nations was created to provide technical assistance to developing countries. It was not a capital fund, but one that emphasized the support of activities designed to attract investment and promote growth in all sectors of the economy. Eight years later all the UN's technical assistance activities were merged into the United Nations Development Programme, the UNDP.

The UNDP obtains its finances by direct, voluntary contributions, mainly from the developed, industrialized nations. Its annual budget is now around US $\$ 700$ million, about 128 of which comes from the U.S.A. (the largest contributor). These funds are allocated among the developing countries in amounts proportional to their populations, and inversely proportional to their GNP per capita. Thus, the more populous and poorer countries in Africa and Asia have been the focus of attention.

Recipient governments divide the funds, in consultation with the UNDP, among the various sectors of their own economies, according to individual national priorities. The UNDP then calls upon appropriate UN Executing Agencies, such as FAO, UNICEF and WHO, to design and implement technical assistance projects, in co-operation with the government. In the mineral sector the designated agency is DTCD, the Department of Technical Co-operation for Development. Although technically a department of the UN Secretariat, DTCD functions as a specialized agency, spending UNDP funds on project personnel, services, training and equipment, and receives a $13 \frac{8}{8}$ overhead on these expenditures, much like a private contracting firm.

The Department's mandate covers development planning and administration, public administration and finance, and population and statistics, but half of its annual budget goes to its Natural Resources Sector (Fig. 1). This is the responsibility of D'TCD's Natural Resources and Energy Division, which has separate branches for minerals, water and energy (including hydrocarbons, geothermal, solar, wind and bio- mass), and one for infrastructure that covers remote sensing, cartography and public works. Of the $\$ 146$ million spent in 1986, \$103 came from the UNDP, with the rest from the UN Fund for Population Activities, from "trust funds" provided by individual governments, and from the UN's "Regular Programme" budget. The total annual project budget of the DTCD Minerals Branch is currently running at about $\$ 17$ million, down from around $\$ 20$ million in 1982, but now on the rise again (see Fig. 2 for the 1987 figures).

The objective of the Minerals Branch is the promotion of mineral resource development, by whatever means are appropriate to the country concerned. Its programs are designed to help both developed and developing countries, by identifying projects worthy of investment. The Branch engages in activities across the whole spectrum from mineral policy, legislation and contracts at one end, through grass roots and detailed exploration, evaluation, feasibility, investment promotion, mining and processing, to marketing. Because of financial constraints - few UNDP projects have budgets in excess of $\$ 2-3$ million - most projects are in the upstream end of the process, in systematic exploration and related work. Contributions to actual mining and processing operations are generally confined to providing expert advice, training or specialized equipment.

The Department is also very active in strengthening institutions. This includes establishing and improving government support facilities such as laboratories and pilot plants, arranging specialized training courses, introducing new technologies such as microcomputer applications, and supplying expert advisors on both short-term and longer term assignments. D'TCD does not engage in research or academic-type education.

\section{DTCD ANNUAL BUDGET 1987}

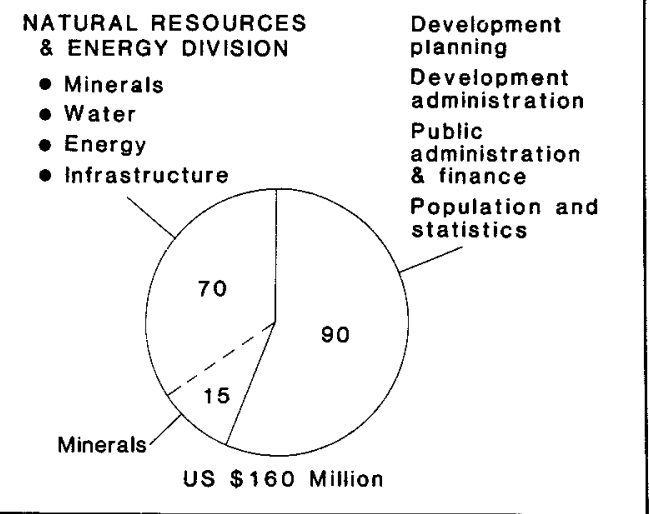

Figure 1: 1987 Budget for the UN Department of Technical Cooperation for Development. 
Technical assistance from the UNDP is offered only to government departments or government-owned agencies; private companies are excluded. Training and participation by national personnel are strongly emphasized in all projects, the aim being to equip the government to undertake mineral resource development work by itself.

\section{Other Mineral Work Within the UN}

The mineral activities of DTCD are complemented by those of a number of other UN agencies. The UN Revolving Fund for Natural Resources Exploration provides exploration financing for countries not adequately covered by other sources (see following article by Tomita and Nichol). Its work is confined to "secondary" (grass-roots) mineral and geothermal exploration. If commercial production results, the Fund will receive royalties, enabling it to "revolve."

The International Atomic Energy Agency is confined to nuclear raw materials: its activities are mainly regulatory, but it also provides limited assistance in exploration. The UN Industrial Development Organization assists in developing mineral-based processing operations. The UN Conference on Trade and Development is concerned with trade in primary commodities, and the achievement for developing countries of prices that are "remunerative, equitable and stable." The UN Centre on Transnational Corporations provides assistance to developing countries in their relations with transnational corporations. UNESCO, the UN Educational, Scientific and Cultural Organization, provides assistance in training and research (see Sibrava, 1987).

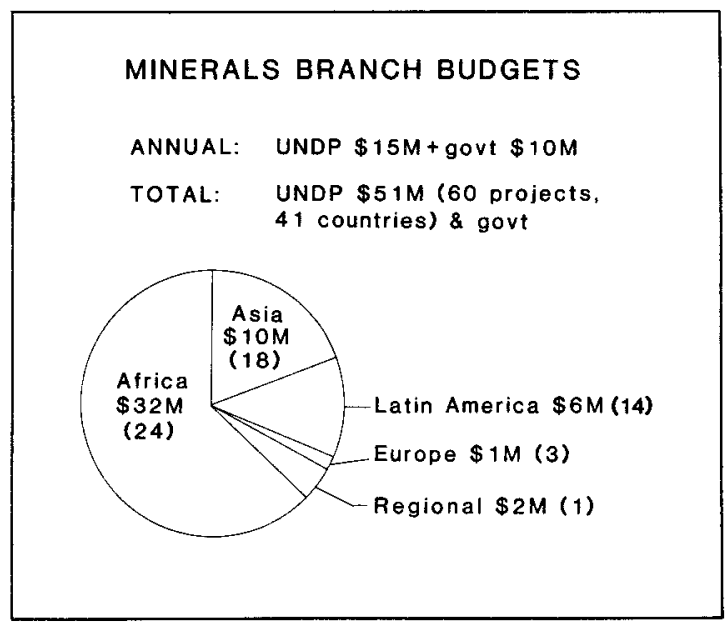

Figure 2: Budget for 1987 for $D T C D$ Minerals Branch.

The Minerals Branch also co-operates with the World Bank, formerly the International Bank for Reconstruction and Development, which provides loans for feasibility studies and mine development. The Bank does not normally engage in exploration, but rather it enters into the picture after a deposit has been identified and outlined. It cannot hold equity in a mining operation, though its affiliate the International Finance Corporation does, but only in private sector ventures. There are also other development banks around the world that may become involved in the mineral sector. These include the Inter-American Development Bank based in Washington D.C., the Islamic Development Bank in Jeddah. Saudi Arabia, the Arab Fund for Economic and Social Development in Kuwait, the African Development Bank in Abidjan, Ivory Coast, and the Asian Development Bank in Manila, Philippines.
UN/DTCD - NATURAL RESOURCES \& ENERGY DIVISION I MINERAL RESOURCES BRANCH

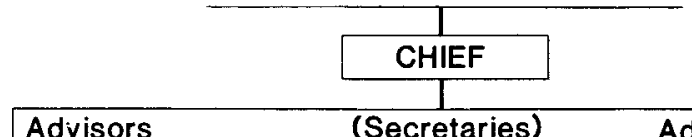

\begin{tabular}{|c|c|c|}
\hline Advisors & (Secretaries) & Administrators \\
\hline $\begin{array}{l}\text { UNDP } \\
\text { (\$15 million) }\end{array}$ & $\begin{array}{l}\text { PROJECTS } \\
\text { - Personnel } \\
\text { - Sub-contracts } \\
\text { - Training } \\
\text { - Equipment } \\
\text { - Misc. }\end{array}$ & $\begin{array}{l}\text { Government } \\
\text { (\$10 million) }\end{array}$ \\
\hline
\end{tabular}

(Latin America, Africa, Asia, etc.)

Figure 3: Organization of the Minerals Branch.

\section{How the Minerals Branch Works}

The Mineral Resources Branch of DTCD (Fig. 3) is located at UN Headquarters in New York City. Under its Chief, it consists of about ten internationally recruited advisors: economic geologists, mining engineers, a geophysicist, a drilling engineer, a computer specialist, and a mining lawyer. Recruitment of project personnel is carried out on an international basis through a computer-based roster in $\mathrm{New}$ York, national centers in industrialized countries, UNDP offices in developing countries, and by direct contact with industry and institutions. The Headquarters staff works in teams, each of which runs $10-15$ projects through the UNDP office in the developing country concerned, and supported at DTCD Headquarters by specialized departments for recruitment, fellowships, contracts and procurement, and accounting. There are no in-house technical support services, such as laboratories.

When a government requires technical assistance in the mineral sector, it requests, through the local UNDP of fice, a visit by a DTCD specialist. The countries that make such requests are mainly ones where other sources of financing and assistance are not readily available. DTCD services are also in demand whenever an independent, objective opinion is required. The Minerals Branch tends to operate especially in places where mining is confined to the public sector or where grassroots exploration is regarded as too risky by private mining companies. By contrast, countries with flourishing mining sectors, like Indonesia and Brazil, or that receive much attention from the international community, like China, tend to have a few or no UN mineral projects.

The DTCD advisor, in consultation with the Government and the UNDP, defines a detailed program of technical assistance and embodies it in a "project document." This is a legal contract between the Government which receives the assistance, the UNDP which finances it, and DTCD which executes it. Following signature, which can take many months, DTCD recruits from international sources and sends to the field the required specialized personnel (geologists, chemists, drillers), arranges the sub-contracts (e.g. for control assays), purchases the field, lab or office equipment and organizes the training courses. 
Ten or fifteen years ago the Minerals Branch often had large expatriate teams of experts in the field, but now many of its projects are managed and run in the field by the country's own geologists and engineers, guided and assisted by periodic visits from the advisor and from highly specialized short-term consultants. This evolution from $90 \%$ foreign resident experts and 108 consultants in the past, to the reverse situation of today reflects the success of $U N$, bilateral and other technical assistance programs over the years, together, of course, with the Governments' own endeavours.

\section{Achievements of the Minerals Branch}

Since 1959 , DTCD has spent some $\$ 300$ million on hundreds of mineral projects in about 100 countries around the world (see Figs. 4 and 5). About 1.1 million line-km of airborne geophysical surveys have been flown, and more than three million geochemical analyses performed. This work has assisted in the discovery of ore deposits whose contents have been valued at many billions of dollars. They include porphyry coppers in Mexico (La Caridad), Panama (Cerro Petaquilla, which led to the Cerro Colorado deposit) and Malaysia (Mamut), the Buck Reef gold deposit in Tanzania, and the Heinze Basin tin-tungsten deposit in Burma.

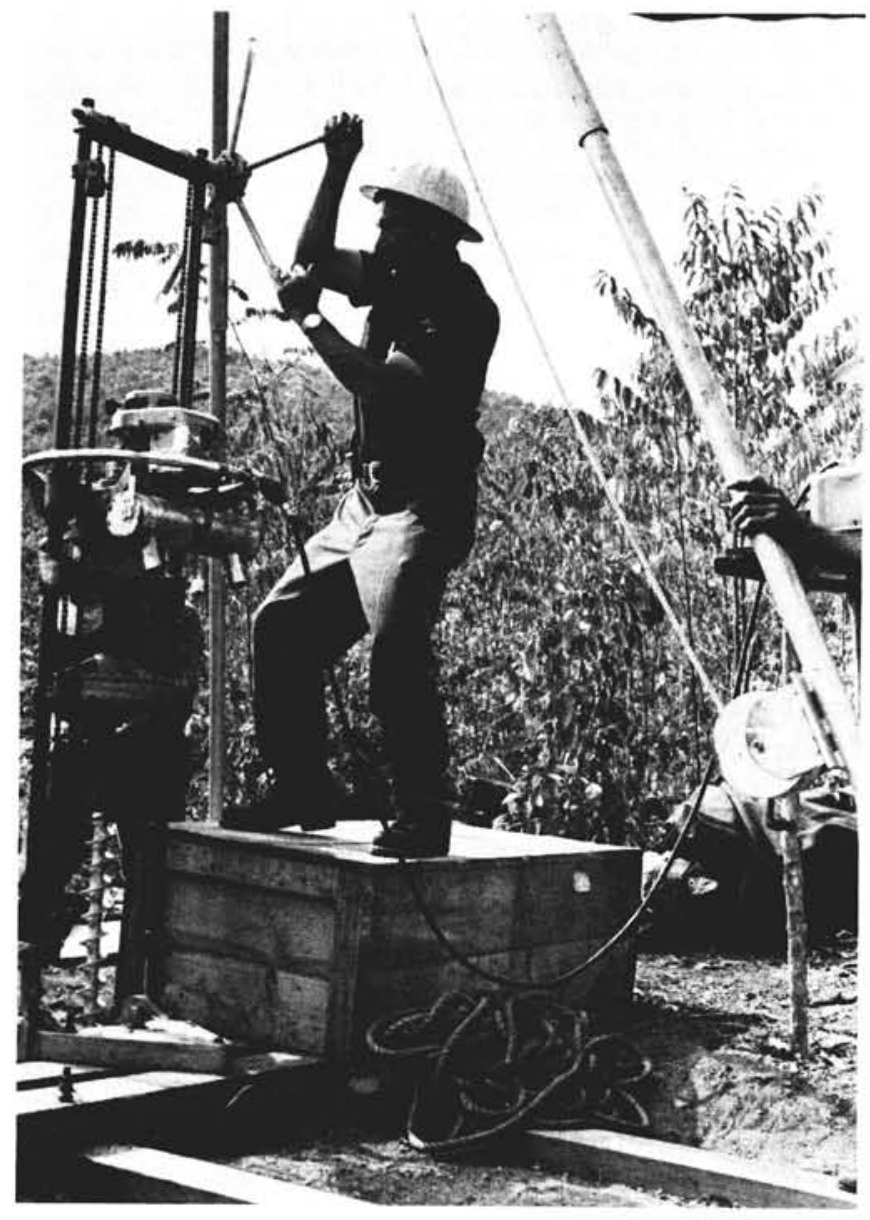

Figure 4: Drilling a nickel laterite deposit, Antioquia Province, Colombia, 1974. Photo by UN/John Littlewood.

In 1982, a major zinc-lead-silver volcanogenic massive sulphide $(\mathrm{Zn}-\mathrm{Pb}-\mathrm{Ag})$ deposit was discovered by geochemistry in a UN project in what is now Burkina Faso. This, like the Cerro Petaquilla discovery, has also opened up a major new metallogenic province for further exploration. In 1985, another UN mineral project in Mali identified widespread

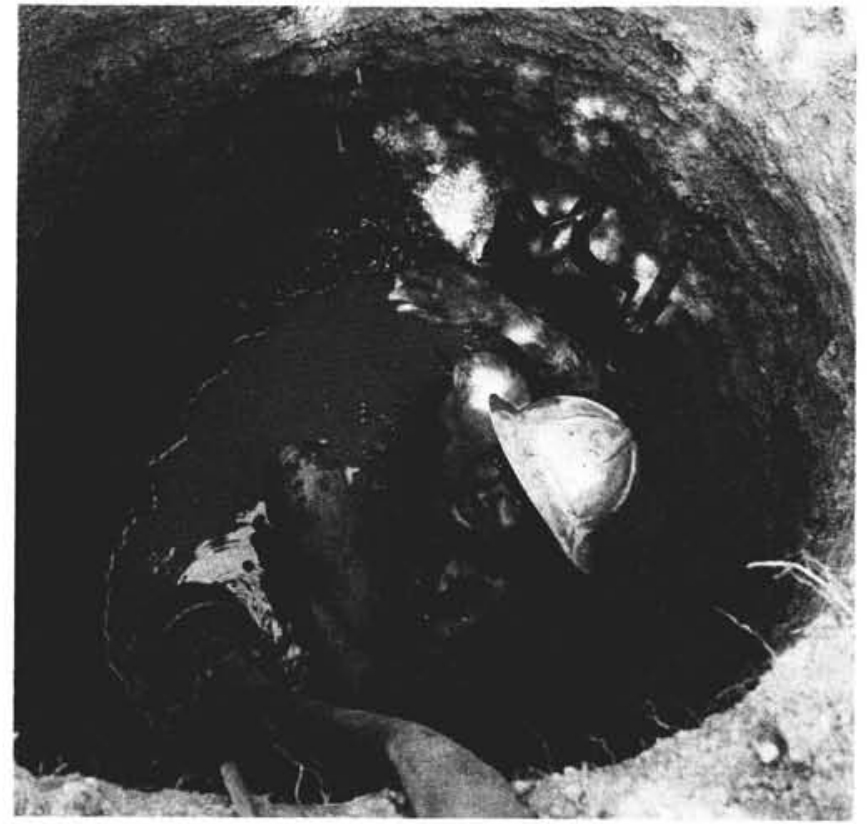

Figure 5: Digging an exploration pit in a dry stream bed in eastern Senegal, as part of a UNDP project on gold, diamonds and chromite. Photo by UN.

gold mineralization southeast of the capital, Bamako - again by geochemistry. With continuing assistance from the UN, the Government of Mali has recently signed a joint venture agreement with BHP's Utah Minerals subsidiary for an initial \$1.5 million investment to explore and develop the area's resources.

Other recent achievements include a project in the Philippines, which has trained national personnel in the latest techniques of epithermal gold exploration and demonstrated its effectiveness by identifying several targets that have attracted the interest of domestic and foreign mining companies and of the UN Revolving Fund. Two gold deposits discovered by the UN in Haiti have also attracted private and Revolving Fund interest.

In Somalia, a major deposit of sepiolite has been evaluated (about 10 million tons at perhaps $\$ 60 /$ ton), and in Mozambique heavy mineral beach sands discovered by a UN project are being investigated by a private company. In recent years extensive airborne geophysical surveys have been conducted in Mauritania, Rwanda, Cameroon, North and South Yemen, and Malawi. All of these have potential for leading to economic targets, and they also provide essential lithologic and structural data often unobtainable by other means. A project in Paraguay resulted in the preparation of geological, hydrogeological and metallogenic maps of the country, of use both for mineral exploration and regional planning purposes.

UN mineral projects also involve non-metallic or industrial minerals. These are commonly simpler and cheaper to develop, and they can contribute significantly and quickly to national economic growth, providing employment, building infrastructure, and often substituting for hard-currency imports. For example, a UN project in Jamaica has discovered high calcium limestone and marble deposits that have attracted investor interest and will help the nation to reduce its present heavy reliance on bauxite. And in Benin, deposits of gravel, clay and marble were evaluated for the local const ruction industry.

There are also other very important facets of the DTCD minerals program. These include training in every aspect of earth science and management, by UN experts on the job, by 
study tours to mines and laboratories overseas, and through fellowships in formal, specialized instruction courses. Institution building and the transfer of technology are other major activities. The Minerals Branch provides equipment of all kinds and advice and instruction in how to use it. In 1986 , the Branch spent $\$ 3.2$ million on equipment alone.

Assistance is also given to the establishment of government units for specialized tasks, such as the creation of a modern, computer-equipped feasibility study group in the Indian Bureau of Mines. The advent of powerful, low-cost microcomputers has enabled DTCD to introduce EDP techniques in the mines departments of many developing countries, and all its larger projects now include computer applications. These range from provision of a single IBM-PC to perform simple word-processing and data management tasks in a West African country, to design of a complete national mineral database for India.

\section{The Example of Airborne Geophysics}

The UN has been involved in many large-scale airborne geophysical surveys over the years. Magnetic coverage is of ten carried out over a large portion of a country prior to regional geological mapping to assist in outlining the dominant structural features in an area and in delineating the distribution of mineral deposits. Gamma ray surveys have often been flown at the same time in order to delineate areas of abnormal uranium content, to map rock types on the basis of their $k, U$ and Th content, or both.

The UN experience with airborne geophysical surveying over the past 25 years has been a mixed one (Table 1). One of the great problems is that of operating in extremely difficult geophysical environments. Many developing countries, for example, lie within areas of tropical rain forest characterized by high average rainfall, high mean annual temperatures, dense jungle growth, profuse drainage systems, rapidly disintegrating surface rocks, deep residual weathering, extensive laterite blankets, difficult access, poor communications and poorly known geology. Other developing countries lie within areas of extensive featureless desert, making navigation and access very difficult. These, coupled with a lack of indigenous exploration experience, expertise, and support services can lead to nightmarish conditions for an airborne geophysical crew.

Over the years the Minerals Branch has slowly and often painfully discovered how to use airborne geophysical methods effectively and has learned from experience that exploration is a multidisciplinary exercise, of which geophysics is only one part. The UN is now carefully reviewing the need for future airborne geophysical surveys, particularly their efficiency in relation to other mineral exploration activities.

\section{Current Projects and Activities}

As of mid-1988, the Minerals Branch is operating nearly 70 projects in 45 countries (see Fig. 6). These have total budgets of some $\$ 55$ million, of which $\$ 17$ million is to be spent in 1988. This does not include the contributions of the host government amounting to about $2 / 3$ of these amounts in the form of national personnel, government equipment, services and facilities of all kinds used by the project. Thus the effective annual total for 1988 is more than $\$ 25$ million, perhaps half of which could be described as exploration related. Twenty-nine of the projects (total UNDP contribution $\$ 35$ million) are in Africa, 15 in Asia and the Pacific (\$12 million), 16 in Latin America and the Caribbean (\$7 million), and 3 in Arab countries ( $\$ 2$ million). Project budgets currently range from as little as $\$ 12,000$ for a visit by a single mining consultant, to as much as $\$ 4.6$ million for a major long-term, integrated exploration project in Mali.

In 1988 , some 80 advisory missions by specialist advisors and consultants will be undertaken, financed from the Department's own budget. These reflect growing requirements of developing countries in such fields as computer applications in mineral exploration and evaluation, investment promotion, mineral development legislation and contract negotiations, and mineral sector planning and institution strengthening.

Another significant activity of the Minerals Branch is the presentation of professional seminars and workshops on specialized topics of importance to the international mineral sector. These are always organized in co-operation with, and with participation from, the host government of the country concerned. One example was the 1986 seminar entitled "The Applications of Electronic Data Processing Methods in Mineral Exploration and Development" held in Sudbury, Canada, and in 1985 a seminar was held in India on gold. Another was the October 1987 seminar in Budapest on "The Role of State Enterprises in the Solid Minerals Industry in Developing Countries."

Specialized earth science training courses are regularly organized by DTCD in co-operation with donor governments, such as the U.S.S.R. The Department also publishes Natural Resources Forum, a quarterly journal of economic, technical and policy issues concerning energy, minerals and water resources.

Finally, DTCD co-operates extensively with other organizations. For example, in Rwanda an airborne survey was made of one half of the country, and the Canadian International Development Agency flew the other half, and in the Philippines the project laboratory performed all the assays for a Japanese bilateral exploration program. The Department may also supply independent technical support for programs undertaken by others. For example in the two Yemens, DTCD provided supervision and quality control for an airborne geophysical survey financed by the Arab Fund, and it is monitoring for the Government the performanee of the Canadian consulting group that is rehabilitating the operations of the State Gold Mining Corporation.

\section{Turning Deposits into Mines}

One of the major objectives is to assist governments in turning deposits into mines. UN policy in undertaking mineral exploration is to carry out investigations until a potentially economic mineral deposit is located. The host government is then asked to decide whether to continue investigations using $U N$ technical services or other private or public organizations to carry the work beyond the preliminary feasibility stage.

In the case of the Perkoa discovery in Burkina Faso, the Government elected to continue the preliminary evaluation work itself. Subsequently $\$ 8$ million in World Bank financing was secured for a pre-feasibility study executed by a consortium led by Pennarroya. Their conclusion was negative,

TABLE 1: Geophysical Sub-Contracts of the DTCD Minerals Branch, 1979-1988

Year Country Project Type Estimated Value (US\$)

\begin{tabular}{|c|c|c|c|}
\hline 1979 & Mauritania & $\begin{array}{l}\text { Airborne magnetics and } \\
\text { radiometrics }\end{array}$ & $\$ 692,000$ \\
\hline 1980 & Tanzania & $\begin{array}{l}\text { Purchase of helicopter EM/ } \\
\text { MAG/RADIOM system }\end{array}$ & 357,000 \\
\hline 1981 & Cameroon & Airborne radiometries & 802,000 \\
\hline 1982 & Rwanda & $\begin{array}{l}\text { Helicopter magnetics and } \\
\text { radiometries }\end{array}$ & 462,000 \\
\hline 1982 & Mauritania & Interpreting airborne data & 123,000 \\
\hline 1983 & Cameroon & Interpreting airborne data & 150,000 \\
\hline $1984 / 85$ & Malawi & $\begin{array}{l}\text { Airborne Mag/Rad/EM } \\
\text { (helicopter) }\end{array}$ & $1,920,000$ \\
\hline $1986 / 87$ & Malawi & Interpreting airborne data & 250,000 \\
\hline $1987 / 88$ & Burkina Faso & Airborne EM (Input) & 800,000 \\
\hline
\end{tabular}

(Average annual expenditure: US\$550,000) 


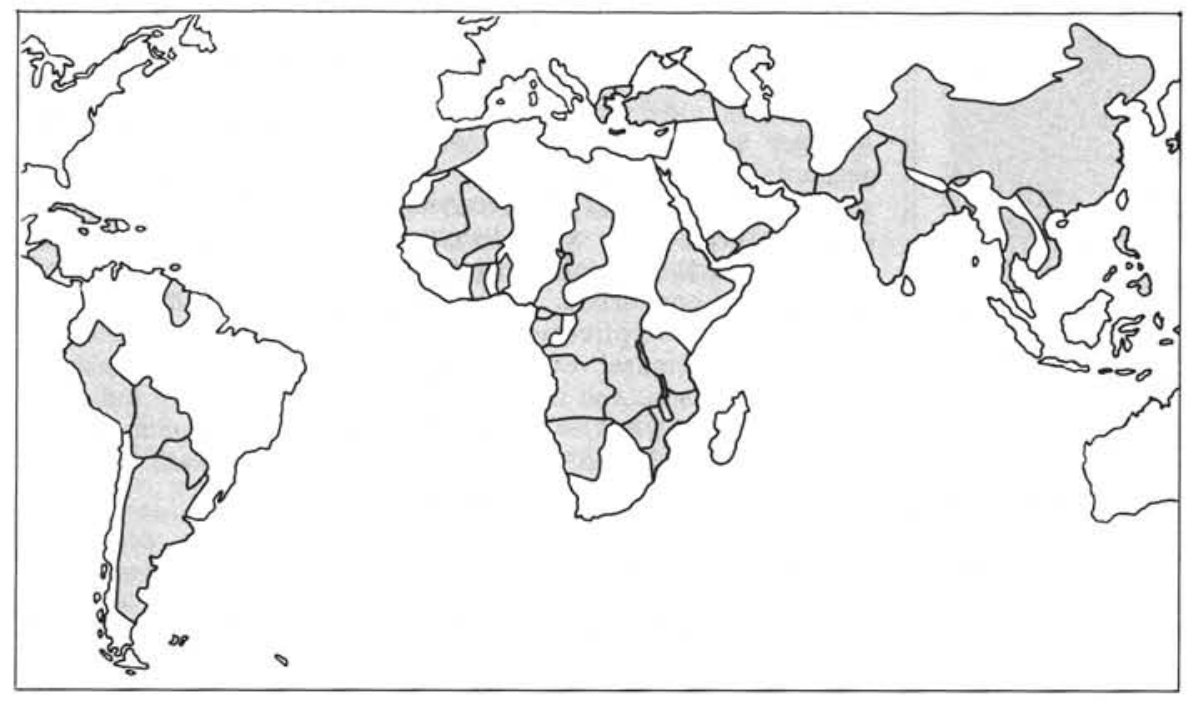

Figure 6: Countries that hosted UN minerals projects in 1987. will include background geographic and economic information on the country, details of the regulatory and fiscal environment, and descriptions of a number of selected regions favourable for gold and other deposits, with pertinent geological and other data.

Thus not only do DTCD programs benefit developing countries, but they also offer opportunities to the world mining industry generally, first through participation in the projects themselves, and second by generating new prospects for investment, as well as new sources of mineral commodities.

Acknowledgements: The writers acknowledge with thanks the assistance of their colleagues in compiling this paper, and the permission of the United Nations Department of Technical Co-operation for Development to present it. but a second study by a Canadian group is more encouraging. Additional discoveries are also expected from an INPUT survey, currently being flown with financing by the Arab Fund.

It is a principle of the UNDP, and thus also of the UN's mineral program, to encourage private sector follow-up and development. The agreement between Mali and BHP/Utah for exploration of gold mineralization found by a UN project was mentioned earlier. The $U N$ is currently assisting the Government of the Dominican Republic in negotiations with Falconbridge over their nickel laterite project.

DTCD is now vigorously involved in investment promotion activities in a number of countries. For many years advice and assistance have been given in the general area of mineral policy, by drafting or modifying mining legislation and regulations to create a more attractive environment for investment. Assistance is also provided to governments in negotiating with foreign companies, for example by supplying legal and mining consultants and more recently by providing computer support for the financial analysis of proposals.

The Department is increasingly engaged in more specific investment promotion, notably through the design and production of national mineral prospectuses. A current example is Guyana, where a model prospectus is being developed in close consultation with the Mines Commissioner. This
Dr. J. Guy-Bray has been Technical Advisor for the UN (Mineral Resources Branch, DTCD, United Nations, New York, NY 10017 , U.S.A.) since 1979. A Canadian, he worked earlier for Anglo American-De Beers in Africa, mainly in diamond exploration, and for INCO in Canada in research, exploration and development. He is currently responsible for design and implementation of DTCD projects in Asia.

Mr. M. Lewis, also a Canadian, is Technical Advisor in Geophysies for DTCD. A graduate of the University of London, he has worked for Scintrex, Hunting and other geophysical groups. At DTCD he is responsible for the design and execution of all geophysical programs in the mineral sector.

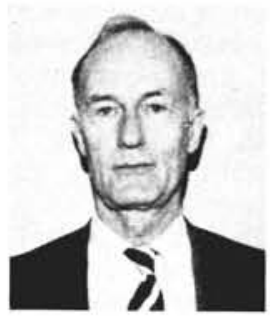

\section{Additional Reading}

Handelsman, S.D., 1986. The United Nations role in the application of microcomputers in mineral projects in developing countries. In Kahmani, R. (ed.), Proceedings 19th International Symposium on the Application of Computers and Operations Research in the Mineral Industry, Society of slining Engineers, $347 \mathrm{p}$.

Harben, P., 1986. The United Nations and mineral development. Industria Minerals, August, p. 60-63.

Lewis, A., 1983. The United Nations in mineral development. Engineering and Mining Journal, January, p. 68-70.

Robson, G. R., 1986. The United Nations and mineral resources development. Natural Resources Forum, v. 10, no. 2, p. 185-188.

Sibrava, V, 1987. The earth sciences in Unesco. Episodes, v. 10, no. 3, p181-186.
UN Secretary-General, 1985. New techniques, including remote sensing, for identifying, exploring and assessing natural resources (Application of computer technology in mineral exploration and technology). UN Report E/C.7/1985/7, New York, 24p.

UN Secretary-General, 1987. Application of microcomputer technology in the assessment, development, and planning of national resources: water, energy and mineral resources. UN Report E/C.7/1987/3, New York, 20p.

United Nations, 1985. Inter-regional Seminar on Gold Exploration and Development, Bangalore, India. UN/DTCD, New York, 403p.

United Nations, 1987. Inter-regional Seminar on the Applications of Electronic Data Processing Methods in Mineral Exploration and Development, Sudbury, Canada. UN/DTCD, New York, 434p.

United Nations Secretariat, 1981. Two decades in mineral resources development. In: Jones, M.J. (ed.), National and International Management of Mineral Resources, Institute of hining and hietalluryy, London, p 163-177. 